http://dx.doi.org/10.6027/US 2014-417

ISBN 978-92-893-2789-3

ANP 2014:729

(C) Nordiska ministerrådet 2014

Layout: Jette Koefoed

Foto: Christiaan Dirksen

Tryck: Rosendahls-Schultz Grafisk

Upplaga: 400

Typsnitt: Meta LF

Papper: Munken Polar

Printed in Denmark

\section{Det nordiska samarbetet}

Det nordiska samarbetet är ett av världens mest omfattande regionala samarbeten. Det omfattar Danmark, Finland, Island, Norge och Sverige samt Färöarna, Grönland och Åland.

Det nordiska samarbetet är politiskt, ekonomiskt och kulturellt förankrat och är en viktig partner i europeiskt och internationellt samarbete. Den nordiska gemenskapen arbetar för ett starkt Norden i ett starkt Europa.

Det nordiska samarbetet ska stärka nordiska och regionala intressen och värderingar i en global omvärld. Gemensamma värderingar länderna emellan bidrar till att stärka Nordens ställning som en av världens mest innovativa och konkurrenskraftiga regioner.

Nordiska ministerrådet

Ved Stranden 18

DK-1061 København K

Telefon (+45) 33960200

www.norden.org 


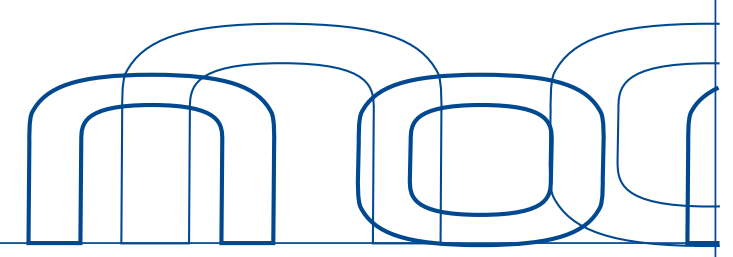

\title{
Hållbar nordisk välfärd
}

\author{
- ett program för nya välfärdslösningar för människor i Norden
}

\section{Bakgrund}

Programmet Hållbar nordisk välfärd realiserar de nordiska statsministrarnas uppmaning till de nordiska hälsoministrarna om att utarbeta konkreta förslag till en vidareutveckling av det nordiska hälsosamarbetet. Det var vid det nordiska statsministermötet den 10 juni 2012 som statsministrarna bad hälsoministrarna om att särskilt se på nordiskt samarbete inom utprövning av nya läkemedel och behandlingar, samarbete om högspecialiserade funktioner samt forskning om hälsa och välfärd.

Hållbar nordisk välfärd, som gäller för perioden 20132015, omfattar utöver en utveckling och konkretisering av det nordiska hälsosamarbetet också konkreta insatser inom utbildnings- och arbetsmarknadsområdet. Det är Ministerrådet för utbildning och forskning (MR-U) och Ministerrådet för social- och hälsopolitik (MR-S) som är de två huvudansvariga ministerråden.

Syftet med Hållbar nordisk välfärd är att bidra med konkreta och innovativa lösningar och verktyg till de nordiska regeringarna för att hantera välfärdspolitiska utmaningar. Lösningarna ska bidra till ökad kvalitet och jämlikhet i utbildning, arbete, samt hälsa och omsorg. Detta uppnås genom att gemensamt finansiera konkreta insatser och skapa nordiska plattformar för dialog och kunskapsutbyte.

Under 2013 och 2014 har ca 50 MDKK allokerats till insatser för Hållbar nordisk välfärd från de nordiska samarbetsministrarnas prioriteringsbudget samt facksektorernas egna budgetar (inkluderat 14 MDKK från ordförandedelen av prioriteringsbudgen).
Hållbar nordisk välfärd realiseras genom konkreta insatser och aktiviteter inom tre insatsområden:
1. Utbildning och arbete för välfärd
2. Forskning för välfärd
3. Infrastruktur för välfärd

Programmet är ett komplement till de nordiska ländernas nationella arbete med att förnya och utveckla välfärden. Stor vikt läggs därför vid att involvera centrala beslutsfattare i länderna. Länderna har också utsett nationella kontaktpersoner för programmet. Det läggs stor vikt vid att se de nordiska processerna och projekten i samband med nationella och europeiska processer och projekt.

I augusti 2013 arrangerades en lanseringskonferens för kontaktpersoner, projektledare, medlemmar i ämbetsmannakommittéer, samt andra nordiska aktörer. Våren 2014 genomförde sekretariatet nationella seminarier i varje land där programmet och de enskilda projekten lyftes fram och diskuterades. Vidare planeras en mittvägskonferens i september 2014. Konferensen ska fokusera på preliminära resultat och kunskapsöverföring.

En viktig del av det fortsatta arbetet 2014 och 2015 är att visa och sprida resultaten, samt följa upp på den oberoende utredning inom det framtida nordiska hälsosamarbetet som de nordiska hälso- och socialministrarna, tillsammans med ministerrådets generalsekreterare, i augusti 2013 tog initiativ till. 

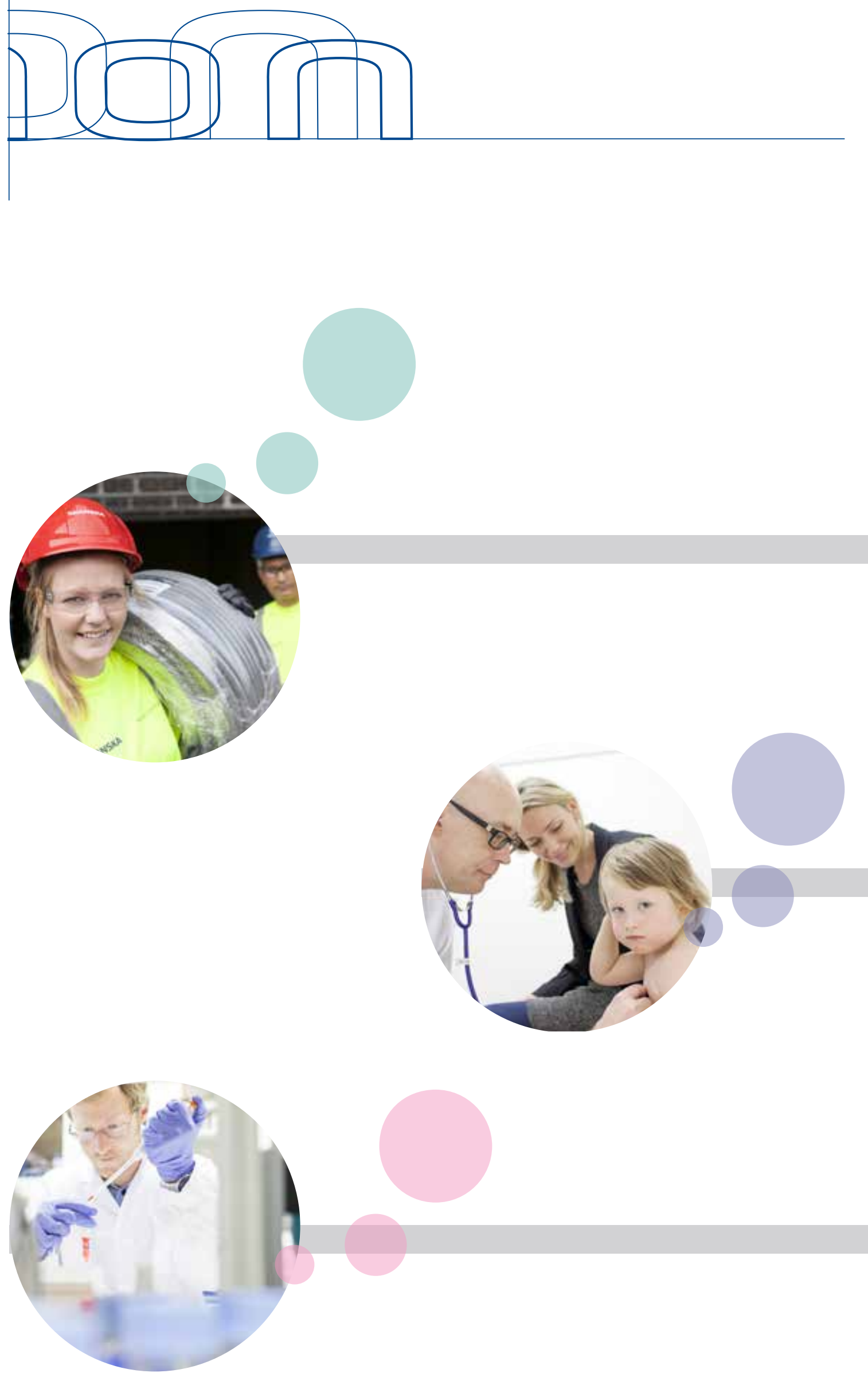


\section{Resumé av arbetet under Hållbar nordisk välfärd}

\section{Hållbar nordisk välfärd realiseras genom konkreta insatser och aktiviteter inom tre insatsområden:}

\section{Utbildning och arbete för välfärd}

Insatser och aktiviteter inom insatsområde 1 ska bidra till att:

- $\quad$ utbildning leder till arbete

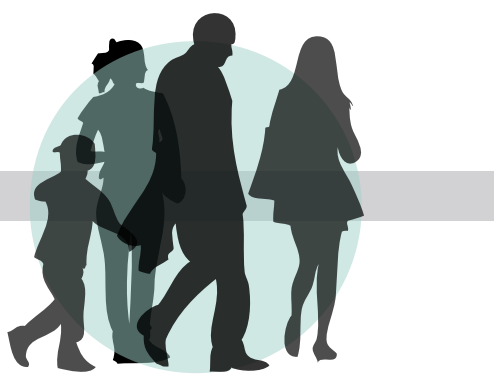

- $\quad$ trygga tillgången på kompetens inom hälso- och omsorgssektorn

Ansvar: Utbildnings- och forskningsministrarna, i samarbete med arbetsministrarna samt social- och hälsoministrarna

\section{Forskning för välfärd}

Insatser och aktiviteter inom insatsområde 2 ska bidra till att:

- främja forskning och framtagande av

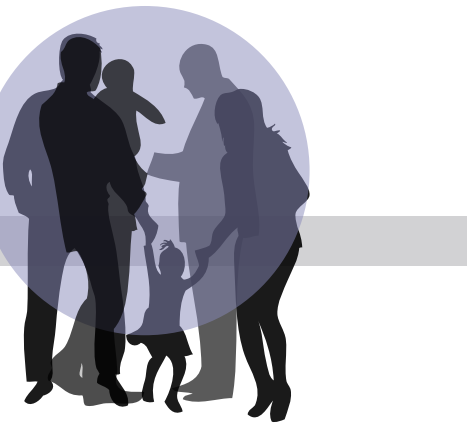
kunskap och modeller som kan bidra till välfärd för alla

Ansvar: Social- och hälsoministrarna i samarbete med utbildnings- och forskningsministrarna

\section{Infrastruktur för välfärd}

Insatser och aktiviteter inom insatsområde 3 ska bidra till att:

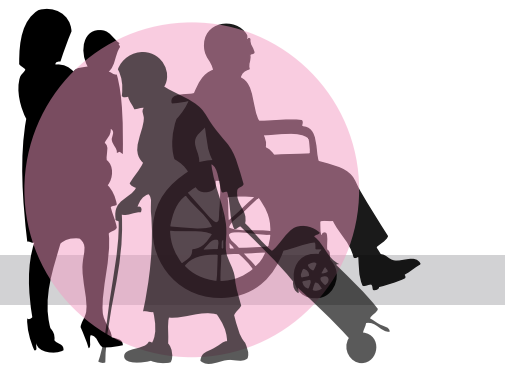

- $\quad$ utveckla och trygga kvaliteten i hälso- och sjukvården

Ansvar: Social- och hälsoministrarna i samarbete med utbildnings- och forskningsministrarna 


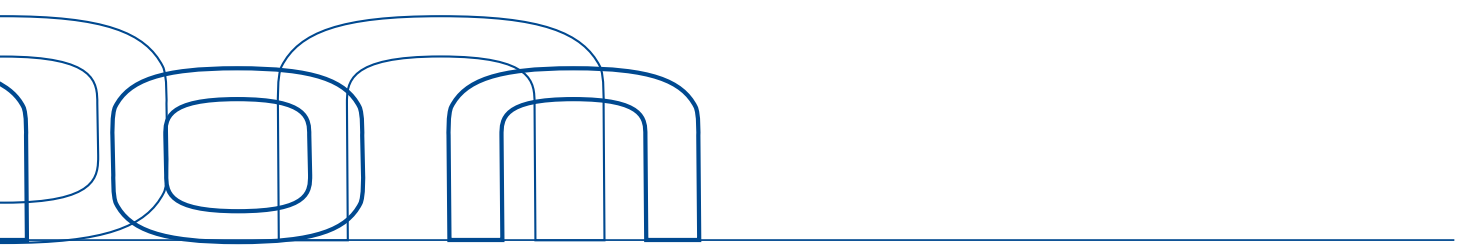

Insatsområde 1: Utbildning och arbete för välfärd

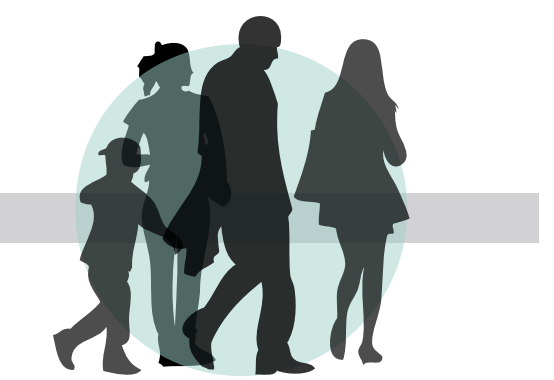

Insatser och aktiviteter inom insatsområde 1

ska bidra till att:

- utbildning leder till arbete

- trygga tillgången på kompetens inom hälso- och omsorgssektorn

Ansvar: Utbildnings- och forskningsministrarna, i samarbete med arbetsministrarna samt socialoch hälsoministrarna

Många avhopp från gymnasie- och yrkesutbildning och ungdomsarbetslöshet i relation till demografiska förändringar är stora utmaningar för den nordiska välfärdsmodellen. Att unga kommer i arbete är viktigt både för att kunna finansiera välfärden i de nordiska länderna och för att säkra ett meningsfullt liv för den enskilde individen.

Rapporten State of the Nordic Region 2013 (Nordregio) visar att antalet äldre i Norden har ökat med 2,8 $\%$ under perioden 2008-2013 och att 27,9 av 100 individer är över 65 år. Det är högre än EU-genomsnittet på 26,8 .

Utmaningarna på arbetsmarknaden varierar mellan länderna. Finlands största utmaning är antalet långtidssjukskrivna. Sveriges är ungdomsarbetslösheten. Norge toppar statistiken för personer med sjuk- eller aktivitetsersättning med $9 \%$ (det nordiska genomsnittet ligger på 6,9\%). Ökningen ses särskilt bland unga.

Följande resultat har uppnåtts halvvägs in i programmet under insatsområde 1. Utbildning för arbete och välfärd:

\section{Lärande på arbetsplatsen}

För att möta utmaningarna med att trygga lärlingoch praktikplatser för personer som går en yrkesutbildning, samt öka kvaliteten i den arbetsplatsförlagda undervisningen, har ministerrådet satt i gång ett projekt om lärande på arbetsplatsen.
Projektet, som leds av Skolverket i Sverige, ska skapa förutsättningar för lokala aktörer att samarbeta med kollegor i andra nordiska länder för att utbyta erfarenheter och på så sätt stimulera det egna utvecklingsarbetet kring lärande på arbetsplatsen. Genom att följa det lokala utvecklingsarbetet från nationell och nordisk nivå ska projektet bidra till lärande och utveckling av lärande på arbetsplatsen.

I projektperioden arrangeras möteplatser i varje land, samt Färöarna och Åland, med ca 100 lokala och nordiska deltagare. Möteplatserna bidrar till nordisk kompetensutveckling mellan deltagare från olika branscher, skolor, myndigheter och organisationer som normalt inte har kontakt med varandra. En slutkonferens arrangeras i Sverige i september 2015, och en slutrapport tas fram.

\section{Nordisk kunskapsbank mot avhopp från skolan} Ungas avtagande möjligheter att komma in på arbetsmarknaden, den ökande ungdomsarbetslösheten och förtidspensioneringen bland unga, samt den ökande andelen av NEETs (Not in Edudation, Employment or Training) i varje årskull utgör en allvarlig utmaning för den nordiska välfärdsmodellens hållbarhet. Upp till 20-40 \% av alla ungdomar som påbörjar en gymnasie- eller yrkesutbildning i Norden, slutför inte sin utbildning inom den utsatta utbildningstiden eller de två följande åren.

Målet med den Nordiska kunskapsbanken mot avhopp är att synliggöra och förmedla relevant kunskap om effektiva förebyggande insatser och andra metoder som bidrar till att fler unga slutför sin utbildning. Kunskapsbanken öppnades hösten 2013 på adressen www.kunnskapsbanken.org och presenteras fortlöpande på olika arrangemang i de nordiska länderna. Arbetet leds av Nordens Välfärdscenter.

\section{Mobilitet och erkännande av yrkeskvalifikationer i Norden}

Norden är ett öppet utbildnings- och arbetsmarknadsområde och möjligheterna för studenter och andra att utbilda sig och arbeta på tvärs av gränser 


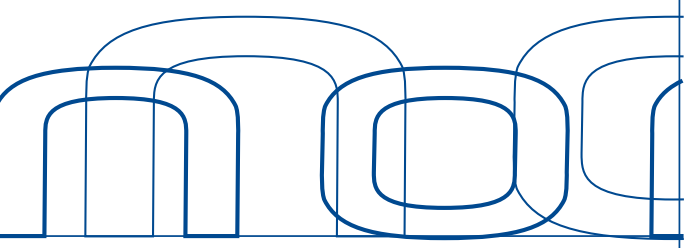

är stora. För att öka mobiliteten och minska gränshinder behövs ett kontinuerligt arbete med att förenkla procedurer för erkännande av utbildning och kompetens. För att bidra till ökad mobilitet har Nordiska ministerrådet kartlagt de nordiska ländernas procedurer och krav på godkännande av nordiska ansökningar till reglerade yrken. Rapporten Lovregulerede erhverv og velfærdsprofessioner i Norden visar också på likheter och skillnader mellan hälso- och omsorgsutbildningar i de nordiska länderna. Detta bidrar till att klargöra kompetensnivåer, som i sin tur kan bidra till ökad mobilitet.

Arbetet följs upp av utbildnings-, hälso-, arbetsmarknads- och näringslivssektorn, samt det nybildade gränshinderrådet som arbetar för att säkra den fria rörligheten i Norden. Det nordiska arbetet koordineras med det nationella arbetet $\mathrm{i}$ implementeringen av EU:S reviderade direktiv om erkännande av yrkeskvalifikationer. I enlighet med ländernas önskemål kommer Nordiska ministerrådet under 2014 att samla fackrådgivare från de ansvariga myndigheterna i länden, för att dela erfarenheter och kunskap om arbetet med implementeringen av direktivet, samt för att främja det nordiska perspektivet i det vidare arbetet med att säkra en transparens och förenkling av direktivet.

\section{Entreprenörskap i utbildningen}

Nordens framtida konkurrensförmåga och välfärd är bland annat beroende av arbetskraftens förmåga att tänka nytt, se möjligheter och omsätta idéer till lösningar. Därför måste de nordiska utbildningssystemen stimulera elevers och studenters förmåga att arbeta kreativt och flexibelt, att ta initiativ och utarbeta innovativa lösningar på samhällets problem. Ett mål med projektet är att sprida den nordiska entreprenörskapskulturen i skolor och att motivera grundskolor att engagera sig i, och att praktisera entreprenöriell undervisning. Syftet är att de unga ska bli bättre förberedda på framtidens arbetsmarknad och att de kan bidra till innovationer och framtidens välfärdslösningar.

Inför en konferens i november 2013 om entreprenörskap i skolan, producerades magasinet Nårjeg bliver stor... I magasinet finns exempel på hur skolor i Norden, på ett aktuellt och konkret sätt, arbetar med entreprenörskap i skolan. Magasinet har distribuerats till skolor för inspiration.
Våren 2014 arbetar olika aktörer i länderna tillsammans för att lyfta fram ytterligare önskemål och behov som kan stärka entreprenörskap i grundskolan och på lärarutbildningar i Norden, med sikte på att implementera dessa hösten 2014 och under 2015.

\section{Andra igångsatta insatser}

Det arbetas för att öka kunskapen om insatser i Norden för främjandet av socialt entreprenörskap och social innovation i inkluderandet av utsatta grupper på arbetsmarknaden och i samhället. Vidare är en analys av den nordiska välfärdsmodellen i färd med att slutföras. Analysen ser över den nordiska välfärdsmodellens tidigare och nuvarande prestationer, framtida utmaningar och möjliga lösningar. Analysen presenteras i samband med de nordiska arbetsmarknadsministrarnas jubileumskonferens på Island i maj 2014.

\section{Ett forskningssamarbete inom välfärdsprofessio-} nerna startar våren 2014 och har som syfte att bidra till ökad kunskap och erfarenhetsutbyte inom forskningen om välfärdsprofessioner, samt ge goda exempel på hur ny kunskap överförs från forskning till utbildning och implementering i praktiken. Vidare genomförs en studie som ska komma med förslag knutna till framtida utmaningar, behov och visioner för det nordiska yrkes- och lärlingssystemet. Rapporten är en uppföljning på det nordiska arbetsmarknadsmötet som arrangerades i Sverige i maj 2013.

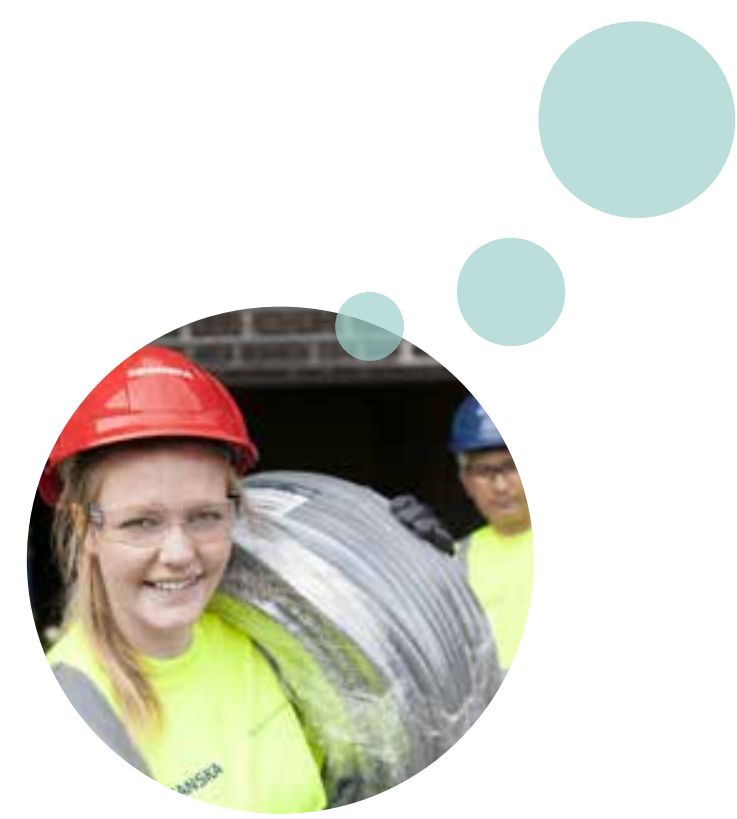




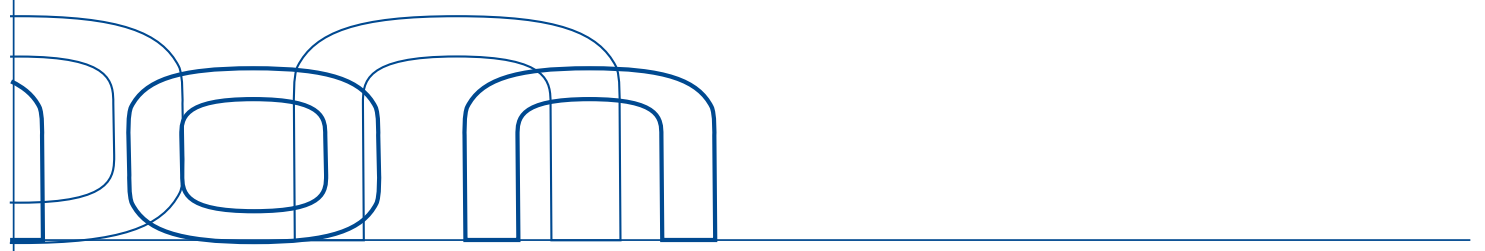

Insatsområde 2: Forskning för välfärd

Insatser och aktiviteter inom insatsområde 2 ska bidra till att:

- främja forskning och framtagande av kunskap och modeller som kan bidra till välfärd för alla

Ansvar: Social- och hälsoministrarna i samarbete med utbildnings- och forskningsministrarna

Livskvaliteten i Norden är bland den högsta i världen. De faktorer som mäter livskvalitet är bland annat hälsa, jobbsäkerhet och jämställdhet mellan könen. Trots detta finns det behov av tvärvetenskaplig kunskap om bakomliggande orsaker till ojämlikhet $\mathbf{i}$ hälsa och välfärd i Norden. Välfärdsforskning handlar om hur människor lever sina liv och hur olika faktorer kan förklara människors levnadsförhållanden.

För att de nordiska länderna även i framtiden ska toppa mätningar om livskvalitet, är det viktigt att vidareutveckla våra välfärdsamhällen inom ett antal områden. Inte minst inom hälsoområdet, där det finns potential för ett ökat nordiskt samarbete och därmed större nordisk nytta.

Följande resultat har uppnåtts halvvägs in i programmet under insatsområde 2. Forskning för välfärd:

\section{Forskning om social ojämlikhet i hälsa och välfärd}

Nordiska ministerrådet finansierar nordisk forskning om sociala ojämlikheter i hälsa och välfärd som undersöker de bakomliggande orsakerna till den ojämna fördelningen av hälsa och välfärd i dagens nordiska samhällen när det kommer till skärningspunkterna mellan kön, social klass, etnicitet, regionala skillnader etc.

Nordiska ministerrådet har allokerat medel till en utlysning av forskningsmedel som kommer att administreras av NordForsk. Utlysningen sker sommaren 2014 inom ramen för NordForsks femåriga forskningsprogram om hälsa och välfärd som har en totalbudget på ca.125 MNOK. Projektet syftar till att intensifiera och stärka nordiskt forskningssamarbete om socioekonomiska skillnader i hälsa och välfärd. Forskningsresultaten blir kunskapsunderlag för att vidta åtgärder som kan bidra till att reducera dessa skillnader och därmed leda till förbättrad hälsa och välfärd i Norden.

\section{Rapport om det framtida nordiska hälsosamarbetet (Könberg-rapporten)}

De nordiska hälso- och socialministrarna har, tillsammans med ministerrådets generalsekreterare, tagit initiativ till en utredning om hur det nordiska samarbetet inom hälsa kan utvecklas och stärkas under de kommande fem till tio åren. Arbetet ska mynna ut i en kortfattad rapport med fokus på rekommendationer och konkreta förslag till lösningar.

Den tidigare svenske ministern Bo Könberg har fått uppdraget att skriva rapporten. Rapporten läggs fram för de nordiska hälso- och socialministrarna på deras möte i juni 2014.

\section{Andra igångsatta insatser}

En nordisk rapport som ser på modeller för rekrytering och behållande av anställda i omsorgssektorn är i färd med att slutföras. Beslut om eventuell uppföljning fattas under hösten 2014. En annan omfattande insats är Välfärdsvakten, som leds av det isländska ordförandeskapet 2014. Syftet är att undersöka de konsekvenser kriser kan ha för de nordiska välfärdssamfunden.

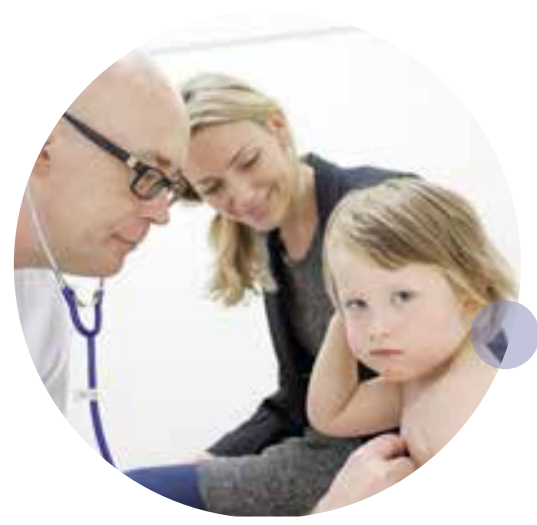




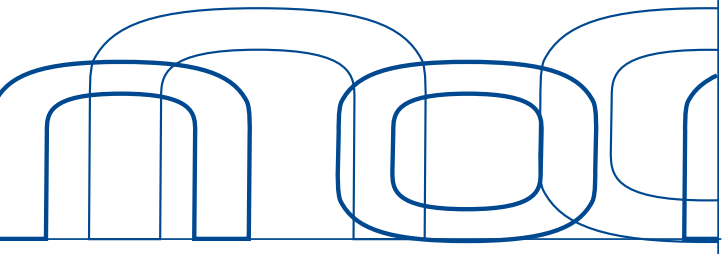

Insatsområde 3: Infrastruktur för välfärd

Insatser och aktiviteter inom insatsområde 3

ska bidra till att:

- $\quad$ utveckla och trygga kvaliteten i hälso- och sjukvården

Ansvar: Social- och hälsoministrarna i samarbete med utbildnings- och forskningsministrarna

Forskning som skapar förutsättningar för en högkvalitativ, patientsäker och kostnadseffektiv hälso- och sjukvård är avgörande för utvecklingen av välfärden. Norden, med sina 26 miljoner invånare, med stora likheter mellan befolkningarna och med spårbara data i systemen, är en guldgruva för forskare. För att kunna använda den information som finns, behövs en ökad koordinering av sociala register, biobanker, utprövning av läkemedel och behandlingar, såväl mellan de nordiska länderna, som mellan registren. Det behövs också ny teknologi för att möta framtida behov inom välfärdssektorn.

Resultaten från insatsområdet ska bidra till bättre underlag för att kunna förebygga sjukdomar, hitta effektivare läkemedel och nya behandlingsmetoder, samt effektiv teknologi.

Följande resultat har uppnåtts halvvägs in i programmet under insatsområde 3. Infrastruktur for välfärd:

\section{Nordiskt samarbete om biobanker, hälsoregister och sociala register}

Under det svenska ordförandeskapet 2013 sattes fokus på att förbättra samspelet mellan de nordiska ländernas forskningsinfrastruktur, bland annat genom ett antal expertseminarier och konferenser rörande forskningsinfrastruktur i regi av bland annat NordForsk, det svenska ordförandeskapet och Nordiska ministerrådet.

Projektets överordnade mål är att stärka ett nordiskt samarbete inom register-, biobanks-, och interven- tionsforskning genom förbättrad tillgång till nordiska datakällor för forskning. För att åstadkomma detta behöver man överkomma existerande hinder som försvårar delning av forskningsdata över länders gränser. Dessa hinder kan vara såväl etiska, legala, tekniska som organisatoriska.

Projektet ska följa upp de konkreta rekommendationer som getts av NordForsks rådgivargrupp “NORIA-net Register” och de åtgärdspunkter som lades fram under sessionen inom hälsa och välfärd på konferensen "Joint Nordic Focus on Research Infrastructures - Looking to the future" som ägde rum i november 2013 (vissa av dessa har redan initierats):

- Erbjuda en samarbetsplattform för nordiska statistikbyråer, nationella hälsoregisterhållare och andra registerhållare med syfte att stärka nordisk forskning.

- I samråd med Nordiska minsiterådet undersöka möjligheter för att uppnå ett ömsesidigt godkännande av etiska prövningstillstånd mellan de nordiska länderna samt diskutera modeller för informerat samtycke.

- Bevaka möjligheter för nordisk samverkan som kan uppstå under pågående revidering av europeisk lagstiftning rörande dataskydd, kliniska prövningar och upphovsrätt. Vid behov och efter samråd med Nordiska minsiterådet, vidta åtgärder.

- Stödja utveckling av tekniska lösningar för säker datahantering t ex genom Nordic e-Infrastructure Collaboration (NeIC).

- I samråd med Nordiska minsiterådet undersöka möjligheter för att skapa lösningar liknande det danska systemet för hälsodata i övriga nordiska länder.

- Utlysa medel till forskningsprojekt och utbildningsprogram för att stödja nordisk registerforskning inom NordForsks program for hälsa och välfärd.

Projektets målgrupp är det nordiska forskarsamhället som lättare ska kunna utnyttja existerande 


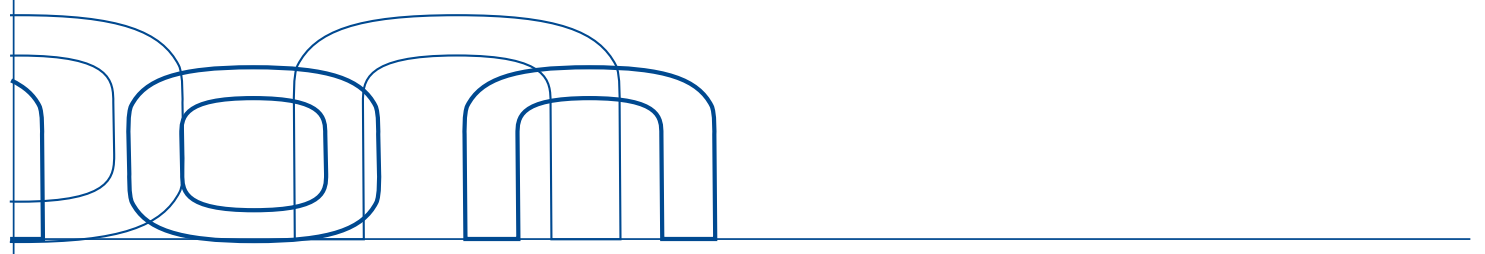

datakällor. Projektet, som leds av NordForsk, kommer dock att involvera flera nationella och nordiska nyckelaktörer. Dessa aktörer inkluderar de nationella forskningsråden, etikkommittéer, statistiska centralbyråer, samt dataskyddsmyndigheter. Här ingår även flera nordiska intressenter; Nordic elnfrastructure collaboration (NeIC), Nordiska bioetikkommittén och existerande nordiska infrastrukturnätverk ( $\mathrm{ex}$ Nordic Trial Alliance, Nordic Biobank Network).

\section{Nordiskt samarbete för kliniska studier}

Kliniska studier, det vill säga undersökningar av effekten av ett läkemedel eller en behandlingsmetod, har minskat drastiskt i Norden de senaste trettio åren. Nordiska ministerrådet via NordForsk arbetar för att förenkla processerna för genomförandet av kliniska studier på tvärs av de nordiska länderna med syftet att öka antalet kliniska studier i Norden. Kliniska studier är en viktig komponent i att introducera nya metoder och behandlingar för patienter.

Nordic Trial Alliance (NTA) syftar till att utöka det nordiska samarbetet inom exempelvis utprövning av nya behandlingsmetoder och läkemedel för att på så vis främja kvalitet, patienttrygghet och hälsa. NTA är i färd med att etablera en databas innehållande pågående nordiska studier som ska underlätta patientrekrytering. Denna databas ska nås via nta. nordforsk.org.

I januari 2014 öppnade NTA en utlysning som syftar till att finansiera ett eller två pilotprojekt som ska visa på det nordiska mervärdet i att expandera natio-

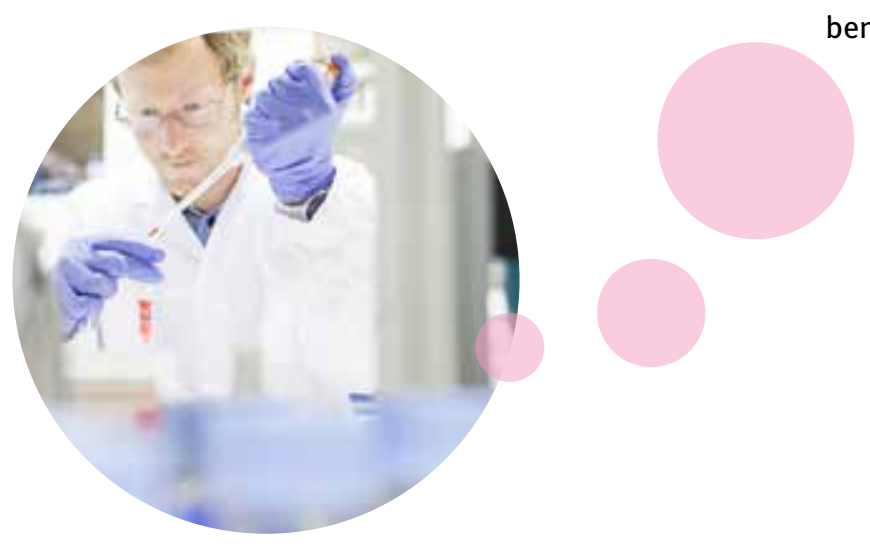

nella kliniska studier till att bli nordiska studier. Besked om vilka projekt som finansieras ges juni 2014.

\section{Nordiskt samarbete om högspecialiserade behandlingar}

Inom sjukvården finns i dag högspecialiserade funktioner där det, på grund av sällsynthet, komplexitet och/eller brist på resurser, kan vara svårt att upprätthålla expertis, erfarenhet, rutin och teknologi. Samarbetet om högspecialiserade behandlingar, som leds av det norska Helsedirektoratet, syftar till att utveckla och beskriva modeller för nordiskt samarbete.

Modellerna utarbetas genom utpekade piloter inom tre områden: nordiska kvalitetsregister, gemensamma nordiska riktlinjer/processer för diagnostik och behandling inom specifika fackområden, samt organisation och strukturering av det professionella samarbetet för kompetensutveckling, kvalitetsfrämjande av behandlingar och patientsäkerhet.

Under 2013 har fyra piloter startat:

- Nordiskt kvalitetsregister för ryggmärgsskador (leds av St. Olavs Hospital, Trondheim, Norge).

- $\quad$ Nordiskt kvalitetsregister for ledproteser i handleder och ankelleder (leds av Haukeland universitetssykehus, Bergen, Norge).

- Samarbete inom barnkirurgi med fokus på medfödda mage-tarm-sjukdomar (leds av Odense Universitetshospital, Danmark).

- Gemensam utbildning av specialister inom fosterdiagnostik med fokus på behandling av foster i livmodern (leds av Rigshospitalet i København, Danmark). 


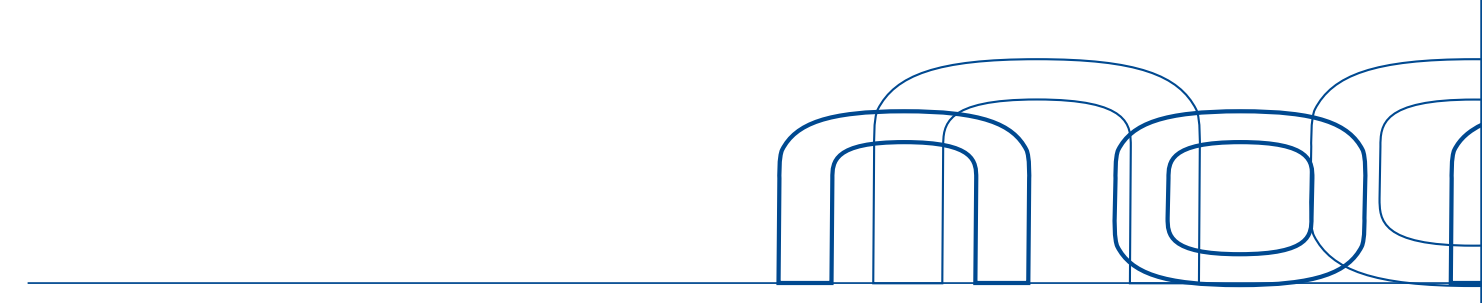

Arbete pågår för att starta ytterligare tre piloter inom området gemensamma nordiska riktlinjer/processer:

- Riktlinjer för behandling av retinoblastom (cancer i ögat som ofta är medfött) (leds av St. Eriks Hospital, Stockholm, Sverige).

- Riktlinjer för kirurgisk korrigerande behandling vid tetraplegi (innebär förlorad funktion i armar, bål, bäckenorgan och ben p.g.a. skada på ryggmärgens halssegment) (leds av Haukeland universitetssykehus, Bergen, Norge).

- Riktlinjer for diagnostik och medicinsk behandling av transsexuella (Leds av Oslo universitetssykehus, Norge).

Projektet syftar också till att ta fram beskrivningar på hur ett nordiskt samarbete inom högspecialiserade behandlingar kan ske inom ramarna för ländernas lagar och politik, samt hur ett etablerat samarbete fortsättningsvis kan säkras inom existerande ekonomiska och organisatoriska ramar. Dessa beskrivningar ska göras tillgängliga för andra fackområden som ser behov av ett nordiskt samarbete med syfte att säkra den professionella utvecklingen, kvaliteten och patientsäkerheten inom det egna området.

\section{Andra igångsatta insatser:}

För att stärka de nordiska kommunernas arbete med välfärdsteknologi, startar Norden välfärdscenter våren 2014 ett arbete för att öka kommunernas implementeringsförmåga och kompetensnivå i förhållande till välfärdsteknologi, stärka förhållandet mellan utbud och vinster, stärka den gemensamma nordiska marknaden, samt stödja existerande nationella strategier.

Läs mer om programmet och de olika projekten på www.norden.org/valfard 


\section{norden}

Nordiska ministerrådet

Ved Stranden 18

DK-1061 København K

www.norden.org

Hållbar nordisk välfärd

- ett program för nya välfärdslösningar för människor i Norden

Programmet Hållbar nordisk välfärd realiserar de nordiska statsministrarnas uppmaning till de nordiska hälsoministrarna om att utarbeta konkreta förslag till en vidareutveckling av det nordiska hälsosamarbetet.

Hållbar nordisk välfärd, som gäller för perioden 2013-2015, omfattar utöver en utveckling och konkretisering av det nordiska hälsosamarbetet också konkreta insatser inom utbildnings- och arbetsmarknadsområdet. Det är Ministerrådet för utbildning och forskning (MR-U) och Ministerrådet för social- och hälsopolitik (MR-S) som är de två huvudansvariga ministerråden.

www.norden.org/valfard 